\title{
Various Enzyme Activities in Muscle and Other Organs of Dystrophic Mice
}

\author{
Takaaki Aoyagi, Takao Wada, Fukiko Kojima, Machiko Nagai, \\ and HAMAO UMEZAWA, Institute of Microbial Chemistry, \\ Kamiosaki, Shinagawa-ku, Tokyo, Japan
}

\begin{abstract}
A B S T R A C T To elucidate the metabolic abnormality of muscular dystrophy, 27 kinds of enzyme activity in various organs of control and dystrophic mice were examined. The organs examined included muscle, bone, heart, testis, uterus, spleen, thymus, submaxillary gland, stomach, pancreas, liver, kidney, brain, and lung. The activities of 14 different aminopeptidases, 5 endopeptidases, 4 glycosidases, phosphatase, esterase, and
\end{abstract} ribonuclease were measured.

Most of the enzyme activities were significantly elevated in muscles and bones of dystrophic mice. These organs were similar in their patterns of enzyme abnormality. Among the 14 kinds of aminopeptidase activity studied, the degree of increased activity was greater for the aminopeptidases (AP):Ala-AP, LeuAP, Met-AP, Phe-AP, Trp-AP, Gly-Pro-Leu-AP. In addition to aminopeptidases, there were significant increases in activities of chymotrypsinlike enzyme, cathepsin $C$, cathepsin $D$, several glycosidases and neutral ribonuclease in the muscles of dystrophic mice.

Similarly increased enzyme activity was also observed in organs other than muscle and bone. Furthermore, protein content in most organs was higher in dystrophic mice than in those of control mice. These abnormalities were seen in both males and females.

The present results suggest that there are extensive abnormalities in the protein metabolism in dystrophic mice. It seems therefore that the therapeutic approach to muscular dystrophy should be studied not only from the well-known abnormality of intramuscular endopeptidases, but from other aspects as well.

\section{INTRODUCTION}

We have found specific inhibitors of various enzymes that can be used as important tools for elucidating different disease processes and are potentially useful in the treatment of diseases (1-4).

Received for publication 17 March 1980 and in revised form 2 September 1980.
There have been several studies suggesting that the increased activities of intramuscular endopeptidases are related to muscular dystrophy in mice (5-13). These observations suggested an application of protease inhibitors in the treatment of muscular dystrophy $(5,6,14-16)$. However, it seemed too early to assume that the destruction of muscle in dystrophy is merely the result of increased activities of intramuscular endopeptidases. To clarify the metabolic abnormality in dystrophic mice, we extensively investigated the activities of various enzymes in muscles and other organs. The activities of aminopeptidases, glycosidases, esterase, and ribonuclease were increased more than endopeptidases. It was suggested that the metabolic processes in dystrophic mice are highly abnormal.

\section{METHODS}

Normal and dystrophic mice. 7-wk-old C57BL/6N of normal and dystrophic mice were obtained from the Central Institute for Experimental Animals, Japan. Mice were killed by cervical dislocation, and organ homogenates were prepared in phosphate-buffered saline $(0.02 \mathrm{M}, \mathrm{pH} 7.2)$ using an Ultra-turrax at the maximum speed for $1 \mathrm{~min}$. The homogenate was centrifuged $(5,000 \mathrm{rpm}, 20 \mathrm{~min})$ and the supernatant fluid was withdrawn to measure enzyme activity. All the enzyme assays were done in triplicate, and their errors were within $10 \%$ of the average values. The values presented are the averages of triplicate assays.

Substrates for enzyme assay. The sources of substrates were as follows: $\mathrm{L}-\boldsymbol{\alpha}$-glutamic acid $\beta$-naphthylamide hydrochloride (L- $\alpha$-Glu-NA.HCl), ${ }^{1}$ L-Arg-NA.HCl, L-Pro-NA. HCl, and L-Met-NA from Mann Research, U. S. A.; Gly-NA.HCl and L-Leu-Gly-Gly-NA from Peptide Institute, Japan; L-

1 Abbreviations used in this paper: Ac(Ala) $)_{3} \mathrm{ME}$, acetyl-Lalanyl-L-alanyl-L-alanine methyl ester; AP, aminopeptidase; ATEE, $N$-acetyl-L-tyrosine ethyl ester; NA, naphthylamide; NPA, $p$-nitrophenyl acetate; NP-AG, $p$-nitrophenyl-N-acetyl$\beta$-D-glucosaminide; NP-Gal, $\boldsymbol{p}$-nitrophenyl- $\beta$-D-galactopyranoside; NP-Glc, $p$-nitrophenyl- $\alpha$-D-glucopyranoside; NPMan, $p$-nitrophenyl- $\alpha$-D-mannopyranoside; NPP, $p$-nitrophenyl-phosphate; TAME; $p$-toluenesulfonyl-L-arginine methyl ester hydrochloride. 
Ala-NA, L-Ser-NA, L-Leu-NA.HCl, L-Phe-NA, L-Trp-NA, GlyL-Pro-NA, L-Ser-L-Tyr-NA, and acetyl-L-alanyl-L-alanyl-Lalanine methyl ester (Ac(Ala) $)_{3} \mathrm{ME}$ ) from Bachem Feinchemikalien AG, Schweiz; $p$-tolue nesulfonyl-L-arginine methyl ester hydrochloride (TAME), $N$-acetyl-L-tyrosine ethyl ester (ATEE), and $p$-nitrophenyl acetate (NPA) from Tokyo Kasei Kogyo Co., Japan; $p$-nitrophenyl- $\alpha$-D-glucopyranoside (NP-Glc), $p$-nitrophenyl- $\alpha$-D-mannopyranoside (NP-Man), and hemoglobin from Calbiochem-Behring Corp., San Diego, Calif.; $p$-nitrophenyl- $\beta$-D-galactopyranoside (NP-Gal), $p$-nitrophenyl- $N$-acetyl- $\beta$-D-glucosaminide (NPAG), and $p$-nitrophenyl phosphate (NPP) from BDH Chemicals Ltd., England; RNA from Boehringer Mannheim, West Germany. Formyl L-methionine $\beta$-naphthylamide (f.Met-NA) and Gly-His-Lys were kindly synthesized by Dr. H. Suda and Dr. T. Yoshioka in our institute.

Determination of enzyme activities. The supernatant fluids of homogenates were dispensed into test tubes (1.5 $\times 10 \mathrm{~cm}$ ) with buffer containing the respective substrates. The test tubes were incubated for $1 \mathrm{~h}$ at $37^{\circ} \mathrm{C}$. For the aminopeptidase (AP) assay, $0.25 \mathrm{ml}$ of $2.0 \mathrm{mM} \beta$-naphthylamide derivative was used as the substrate. After the reaction, 1.0 $\mathrm{ml}$ of a solution of the stabilized diazonium salt Garnet GBC $(1 \mathrm{mg} / \mathrm{ml}$, in $1 \mathrm{M}$ acetic-acid buffer at $\mathrm{pH} 4.2$, containing $10 \%$ Tween 20 ) was added, and the mixture kept for $15 \mathrm{~min}$ at room temperature; the absorbance at $525 \mathrm{~nm}$ was determined (17). For the endopeptidase assay, $0.1 \mathrm{ml}$ of $75 \mathrm{mM}$ ester of peptide or $\mathrm{N}$-acylaminoacid was used as the substrate; after the reaction, $2.0 \mathrm{ml}$ of alkaline hydroxylamine solution ( $2 \mathrm{M}$ hydroxylamine. $\mathrm{HCl}$ mixed with equal volume of $3.5 \mathrm{~N} \mathrm{NaOH}$ ) was added, and the mixture kept for $30 \mathrm{~min}$ at room temperature. $1.0 \mathrm{ml}$ of $12 \%$ hydrochloric acid solution containing trichloracetic acid at $6 \%$ was added. $1 \mathrm{ml}$ of this solution was added to $4.0 \mathrm{ml}$ of ferric chloride $(0.11 \mathrm{M})$ in $0.04 \mathrm{~N} \mathrm{HCl}$ and the absorbance at $525 \mathrm{~nm}$ was measured (18). For the cathepsin-D assay, $1.0 \mathrm{ml}$ of $0.5 \%$ hemoglobin solution ( $\mathrm{pH} 2.0$ ) was used as the substrate. $2.0 \mathrm{ml}$ of $1.7 \mathrm{M}$ perchloric acid was added after the reaction, and the mixture was kept for $1 \mathrm{~h}$ at room temperature. The supernatant fluid was withdrawn by centrifugation $(3,000 \mathrm{rpm}, 5 \mathrm{~min})$ and the absorbance at $280 \mathrm{~nm}$ was determined (19). For the glycosidase assay, $0.05 \mathrm{ml}$ of $50 \mathrm{mM} p$-nitrophenyl derivative was used as the substrate. The reaction was terminated by the addition of $0.2 \mathrm{ml}$ of $0.4 \mathrm{M}$ glycine- $\mathrm{NaOH}$ buffer ( $\mathrm{pH} 10.5$ ), and the mixture was centrifuged at $3,000 \mathrm{rpm}$ for $5 \mathrm{~min}$. The supernatant fluid was withdrawn and the absorbance at $400 \mathrm{~nm}$ was determined (20). For phosphatase and esterase assay, $0.03 \mathrm{ml}$ of $50 \mathrm{mM} p$-nitrophenyl derivative was used as the substrate. After the reaction, the mixture was processed in a way similar to the glycosidase assay. The absorbance was measured at $420 \mathrm{~nm}$ for the phosphatase assay, and at $400 \mathrm{~nm}$ for the esterase assay (21). For RNase assay, a slight modification of the method of Meyer et al. (22) was used. $0.25 \mathrm{ml}$ of $2 \%$ RNA from yeast with or without $p$-hydroxymercuriphenylsulfonate was used as the substrate to measure the activities of free and total RNase, respectively. After the reaction at $\mathrm{pH} 7.6,0.5 \mathrm{ml}$ of stop solution (uranyl acetate $0.75 \%$ in $25 \%$ perchloric acid) was added and the mixture kept for $1 \mathrm{~h}$ in ice water. The supernatant fluid was withdrawn by centrifugation, and the absorbance at $260 \mathrm{~nm}$ was measured. Free RNase activity is defined as activity measured without $p$-hydroxymercuriphenylsulfonate, and total RNase is the activity measured with this agent. According to Meyer et al. (22), the latter is considered to include free RNase and RNase bound to an intrinsic inhibitor.

Protein determination. The method of Lowry et al. (23) was used, with bovine serum albumin as the standard.

\section{RESULTS}

Fig. 1 $a$ illustrates the time-course of the enzyme reaction in the homogenate of the forelimb muscle of normal and dystrophic mice. The catalytic activities of AP A and Leu-AP increased linearly for at least $60 \mathrm{~min}$. Also, as shown in Fig. 1b, AP activities in the homogenate were linear with respect to the protein concentration in the assay medium, which was used as an index of the enzymes contained. All other assays were similarly linear with time and enzyme concentrations. All the enzyme assays were done in triplicate and their errors were within $10 \%$ of the average values.

To assess the behavior of each enzyme, statistical analysis was done with respect to activities of the 27 kinds of enzyme in muscle and in bone (Tables I and II). In this case, the enzyme activity is expressed in nanomolars of reaction products per minute per $1 \mathrm{~g}$ wet wt of organs. The activities for the fore limbs and the hind limbs of both sexes were combined. This treatment can be justified from the similarity of their enzyme activities. In muscle, most significant increases were seen in the activities of Gly-AP, Met-AP, Phe-AP, Trp-AP, Gly-Pro-Leu-AP, GlyHis-Lys-AP, cathepsin C, $\alpha$-D-glucosidase, $N$-Ac$\beta$-D-glucosaminidase, free RNase, and total RNase ( $P$ $<0.001)$. The increased activity of AP-A, Ala-AP, SerAP, Leu-AP, Gly-Pro-AP, chymotrypsin-like enzyme, and $\beta$-D-galactosidase were highly significant $(P<0.01)$. Significant increases were also seen in the activity of
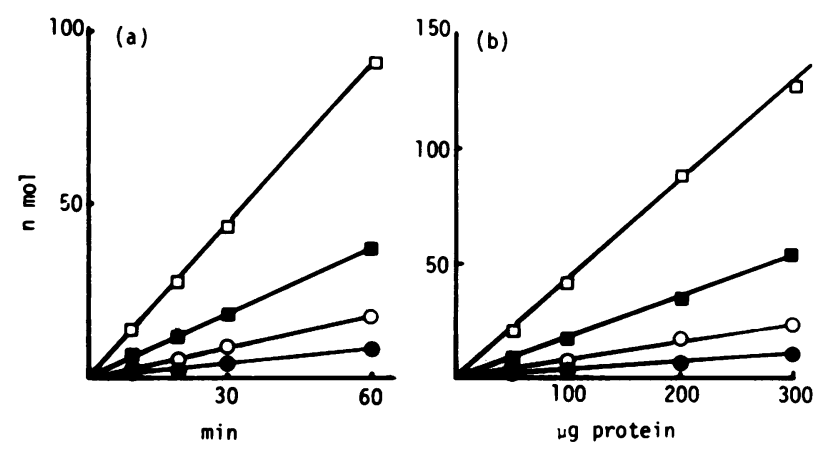

Figure 1 (a) Time-course of aminopeptidase activities in muscle of normal and dystrophic male mice. The hydrolysis of glutamic acid $\beta$-naphthylamide (Glu-NA) and Leu-NA were determined on the homogenate of fore-limb muscle. Enzyme activities are expressed as nanomoles of naphthylamine per $200 \mu \mathrm{g}$ protein in homogenate. Each point was obtained from the average of triplicate samples. O, Glu-NA (dystrophy); O, Glu-NA (normal); $\square$, Leu-AP (dystrophy); a, Leu-AP (normal). (b) Proportion of enzyme activities to protein content in homogenate. Enzyme activities are expressed nanomoles of naphthylamine per hour. Each point was obtained from the average of triplicate samples. $O$, Glu-NA (dystrophy); O, Glu-NA (normal); $\square$, Leu-AP (dystrophy); $\mathbf{\square}$, Leu-AP (normal). 
TABLE I

Comparison of 27 Enzyme Activities in Muscle in Control and Dystrophy When Expressed as Specific Activity per Gram Wet Weight of Organ

\begin{tabular}{|c|c|c|c|c|}
\hline \multirow[b]{2}{*}{ Enzyme } & \multirow[b]{2}{*}{ Substrate } & \multicolumn{2}{|c|}{ Activities $^{*} \pm S D$} & \multirow{2}{*}{$\begin{array}{l}\text { Significance of } \\
\text { difference }\end{array}$} \\
\hline & & Control $(n=4)$ & Dystrophy $(n=4)$ & \\
\hline AP-A & Glut-NA & $27.9 \pm 7.2$ & $76.2 \pm 17.4$ & $P<0.01$ \\
\hline AP-B & Arg-NA & $191 \pm 55$ & $245 \pm 58$ & NS \\
\hline Gly-AP & Gly-NA & $24.7 \pm 7.8$ & $95.5 \pm 14.5$ & $P<0.001$ \\
\hline Ala-AP & Ala-NA & $216 \pm 29$ & $643 \pm 78$ & $P<0.01$ \\
\hline Ser-AP & Ser-NA & $19.0 \pm 5.1$ & $40.1 \pm 9.2$ & $P<0.01$ \\
\hline Pro-AP & Pro-Na & $40.3 \pm 15.0$ & $48.2 \pm 17.2$ & NS \\
\hline Leu-AP & Leu-NA & $137 \pm 31$ & $352 \pm 50$ & $P<0.01$ \\
\hline Met-AP & Met-NA & $176 \pm 35$ & $534 \pm 56$ & $P<0.001$ \\
\hline f $\cdot$ Met-AP & f $\cdot$ Met-NA & $197 \pm 24$ & $208 \pm 23$ & NS \\
\hline Phe-AP & Phe-NA & $190 \pm 49$ & $564 \pm 55$ & $P<0.001$ \\
\hline Trp-AP & Trp-NA & $36.6 \pm 10.5$ & $145 \pm 21$ & $P<0.001$ \\
\hline Gly-Pro-AP & Gly-Pro-NA & $20.0 \pm 4.4$ & $39 \pm 7$ & $P<0.01$ \\
\hline Gly-Pro-Leu-AP & Gly-Pro-Leu-NA & $18.8 \pm 5.4$ & $36 \pm 2$ & $P<0.001$ \\
\hline Gly-His-Lys-AP & Gly-His-Lys-NA & $3.2 \pm 1.8$ & $18 \pm 3$ & $P<0.001$ \\
\hline Trypsinlike & TAME & $605 \pm 292$ & $402 \pm 221$ & NS \\
\hline Chymotrypsinlike & ATEE & $456 \pm 166$ & $849 \pm 157$ & $P<0.01$ \\
\hline Elastaselike & $\mathrm{Ac}(\mathrm{Ala})_{3} \mathrm{ME}$ & $278 \pm 263$ & $714 \pm 363$ & $P<0.1$ \\
\hline Cathepsin C & Ser-Tyr-NA & $15 \pm 3$ & $68.6 \pm 15.2$ & $P<0.001$ \\
\hline Cathepsin DI & Hemoglobin & $0.10 \pm 0.02$ & $0.22 \pm 0.05$ & $P<0.01$ \\
\hline$\alpha$-D-Glucosidase & NP-Glc & $7.7 \pm 3.4$ & $19.2 \pm 1.6$ & $P<0.001$ \\
\hline$\beta$-D-Galactosidase & NP-Gal & $1.8 \pm 2.2$ & $6.6 \pm 4.7$ & $P<0.01$ \\
\hline$\alpha$-D-Mannosidase & NP-Man & $3.1 \pm 3.6$ & $9.1 \pm 1.3$ & $P<0.05$ \\
\hline$N$-Ac- $\beta$-D-Glucosaminidase & NP-AG & $6.6 \pm 2.4$ & $45.0 \pm 10.8$ & $P<0.001$ \\
\hline Phosphatase & NPP & $48.7 \pm 18.3$ & $82.9 \pm 30.3$ & NS \\
\hline Esterase & NPA & $484 \pm 553$ & $3,655 \pm 2,219$ & $P<0.1$ \\
\hline RNase $\$$ (free) & RNA & $40.7 \pm 8.0$ & $255 \pm 59$ & $P<0.001$ \\
\hline RNase (total) & RNA & $175 \pm 41$ & $426 \pm 84$ & $P<0.001$ \\
\hline
\end{tabular}

* Enzyme activities are expressed as nanomoles per minute per gram wet weight.

† Cathepsin D activity is expressed as absorbance at $280 \mathrm{~nm} / \mathrm{min} / \mathrm{g}$ (wet wt).

\&Nase activities are expressed as unit per gram (wet weight). $1 \mathrm{U}$ is equivalent to the activity of $1 \mathrm{ng}$ standard RNase from bovine pancreas.

$\alpha$-D-mannosidase $(P<0.05)$. Possibly significant increases were seen in the activities of elastaselike enzyme and esterase $(P<0.1)$. Only trypsinlike enzyme activity tended to decrease in dystrophic mice, although this decrease was not statistically significant. The remaining four kinds of enzymes tended to increase but without statistical significance.

In bone, most significant increases were seen in the activities of Ala-AP, Phe-AP, Trp-AP, free RNase, and total RNase $(P<0.001)$. Highly significant increases were seen in those of AP-A, AP-B, Gly-AP, Ser-AP, Leu-AP, Met-AP, Gly-Pro-Leu-AP, chymotrypsinlike enzymes, and $N$-Ac- $\beta$-D-glucosaminidase $(P<0.01)$. Significant increases were seen in the activities of Gly-Pro-AP, Gly-His-Lys-AP, trypsinlike enzyme, cathepsin $C$, cathepsin $D$, and esterase $(P<0.05)$. Possibly significant increases were seen in the activi- ties of f.Met-AP, $\alpha$-D-mannosidase, and phosphatase $(P<0.1)$.

In Tables III and IV, the activities are expressed in terms of specific activity per minute per milligram of protein in organs. In muscle, the most significant differences in activity were seen with Gly-AP, Ala-AP, Leu-AP, Met-AP, Phe-AP, Trp-AP, Gly-His-Lys-AP, $N$-Ac- $\beta$-D-glucosaminidase, and free RNase $(P<0.001)$. Highly significant differences were seen with AP A, cathepsin C, $\alpha$-D-galactosidase, and total RNase ( $P$ $<0.01)$. A significant difference was seen in the activities of Ser-AP, Gly-Pro-Leu-AP, cathepsin D, $\beta$-Dgalactosidase, $\alpha$-D-mannosidase, and esterase $(P<0.05)$.

Biochemists conventionally use specific activity per milligram of protein to standardize enzyme activities. However, it is not clear that this is the only good way, because a change in the amount of nonspecific protein 
TABLE II

Comparison of 27 Enzyme Activities in Bone in Control and Dystrophy When Expressed as Specific Activity per Gram Wet Weight of Organ

\begin{tabular}{|c|c|c|c|c|}
\hline \multirow[b]{2}{*}{ Enzyme } & \multirow[b]{2}{*}{ Substrate } & \multicolumn{2}{|c|}{ Activities* \pm SD } & \multirow{2}{*}{$\begin{array}{l}\text { Significance of } \\
\text { difference }\end{array}$} \\
\hline & & Control $(n=4)$ & Dystrophy $(n=4)$ & \\
\hline AP-A & Glut-NA & $42.8 \pm 1.2$ & $80.8 \pm 8.1$ & $P<0.01$ \\
\hline AP-B & Arg-NA & $180 \pm 27$ & $308 \pm 49$ & $P<0.01$ \\
\hline Gly-AP & Gly-NA & $23.8 \pm 4.7$ & $54.8 \pm 11.5$ & $P<0.01$ \\
\hline Ala-AP & Ala-NA & $272 \pm 49$ & $513 \pm 49$ & $P<0.001$ \\
\hline Ser-AP & Ser-NA & $9.13 \pm 1.79$ & $19.8 \pm 4.9$ & $P<0.01$ \\
\hline Pro-AP & Pro-Na & $23.5 \pm 4.0$ & $30.8 \pm 11.3$ & NS \\
\hline Leu-AP & Leu-NA & $159 \pm 22$ & $302 \pm 9$ & $P<0.01$ \\
\hline Met-AP & Met-NA & $222 \pm 31$ & $475 \pm 27$ & $P<0.01$ \\
\hline f $\cdot$ Met-AP & f $\cdot$ Met-NA & $210 \pm 33$ & $245 \pm 13$ & $P<0.1$ \\
\hline Phe-AP & Phe-NA & $205 \pm 27$ & $420 \pm 42$ & $P<0.001$ \\
\hline Trp-AP & Trp-NA & $48.5 \pm 8.3$ & $99.1 \pm 14.9$ & $P<0.001$ \\
\hline Gly-Pro-AP & Gly-Pro-NA & $29.2 \pm 2.8$ & $39.4 \pm 5.9$ & $P<0.05$ \\
\hline Gly-Pro-Leu-AP & Gly-Pro-Leu-NA & $15.1 \pm 2.8$ & $24.4 \pm 2.6$ & $P<0.01$ \\
\hline Gly-His-Lys-AP & Gly-His-Lys-NA & $3.0 \pm 3.1$ & $8.4 \pm 2.8$ & $P<0.05$ \\
\hline Trypsinlike & TAME & $691 \pm 151$ & $1,125 \pm 322$ & $P<0.05$ \\
\hline Chymotrypsinlike & ATEE & $368 \pm 164$ & $1,035 \pm 308$ & $P<0.01$ \\
\hline Elastaselike & $\mathrm{Ac}(\mathrm{Ala})_{\mathbf{3}} \mathrm{ME}$ & $610 \pm 164$ & $743 \pm 200$ & NS \\
\hline Cathepsin C & Ser-Tyr-NA & $22.4 \pm 2.7$ & $34.4 \pm 7.3$ & $P<0.05$ \\
\hline Cathepsin D & Hemoglobin & $0.41 \pm 0.06$ & $0.64 \pm 0.17$ & $P<0.05$ \\
\hline$\alpha$-D-Glucosidase & NP-Glc & $9.8 \pm 2.8$ & $26.3 \pm 10.6$ & $P<0.05$ \\
\hline$\beta$-D-Galactosidase & NP-Gal & $15.5 \pm 6.3$ & $19.9 \pm 1.5$ & NS \\
\hline$\alpha$-D-Mannosidase & NP-Man & $4.0 \pm 3.9$ & $11.4 \pm 5.0$ & $P<0.1$ \\
\hline$N$-Ac- $\beta$-D-Glucosaminidase & NP-AG & $48.3 \pm 15.2$ & $122 \pm 23$ & $P<0.01$ \\
\hline Phosphatase & NPP & $274 \pm 100$ & $158 \pm 48$ & $P<0.1$ \\
\hline Esterase & NPA & $553 \pm 636$ & $2,036 \pm 751$ & $P<0.05$ \\
\hline RNase $\$($ free) & RNA & $274 \pm 69$ & $675 \pm 61$ & $P<0.001$ \\
\hline RNase (total) & RNA & $359 \pm 84$ & $728 \pm 87$ & $P<0.001$ \\
\hline
\end{tabular}

* Enzyme activities are expressed as nanomoles per minute per gram wet weight.

t See the footnotes to Table I.

$\S$ See footnotes to Table I.

in tissues can influence this parameter, regardless of enzyme content in the tissues. Hence we present not only Tables III and IV but also Tables I and II. Comparing the results in Tables I and II with those in Tables III and IV, the $t$ values for 27 enzyme activities tended to decrease in the latter two. This means that the increase of enzyme activity became less apparent when corrected for protein contents in organs and was clearly because of increased protein concentration in organs of dystrophic mice. This tendency was more striking in bone. In this organ significant difference between dystrophic and control animals was seen only in relation to AP-A, Gly-AP, Leu-AP, Met-AP, Phe-AP, $N$-Ac- $\beta$-glucosaminidase, and free RNase.

In Fig. 2, the protein contents of 15 different organs of dystrophic mice are compared with those of the controls. As seen from the figure, they were increased in most organs of dystrophic mice. The increases were statistically significant $(P<0.05$ for male and $P<0.005$ for female).

In addition to these observations, we tried to study the behavior of enzymes in various organs other than muscle and bone. However, it was hard to decide whether or not the increase of a particular enzyme in a particular organ was statistically significant. To do so, we would have had to repeat measurements of too many samples. Instead we studied the behavior of a series of aminopeptidases as a whole.

This approach seems justified from the close correlation among the increases of various aminopeptidases. Taking fore-limb muscle as an example, one can see in Fig. 3 that the points representing each aminopeptidase seem to lie along a regression line. If there were not any correlations among them, the points would be widely scattered above the unit line, meaning that each aminopeptidase increased only at random in 
TABLE III

Comparison of 27 Enzyme Activities in Muscle in Control and Dystrophy When Expressed as Specific Activity per Milligram of Protein

\begin{tabular}{|c|c|c|c|c|}
\hline \multirow[b]{2}{*}{ Enzyme } & \multirow[b]{2}{*}{ Substrate } & \multicolumn{2}{|c|}{ Activities* $\pm S D$} & \multirow{2}{*}{$\begin{array}{l}\text { Significance of } \\
\text { difference }\end{array}$} \\
\hline & & Control $(n=4)$ & Dystrophy $(n=4)$ & \\
\hline AP-A & Glut-NA & $0.73 \pm 0.08$ & $1.68 \pm 0.32$ & $P<0.01$ \\
\hline AP-B & Arg-NA & $5.02 \pm 1.11$ & $5.38 \pm 1.14$ & NS \\
\hline Gly-AP & Gly-NA & $0.65 \pm 0.17$ & $2.10 \pm 0.27$ & $P<0.001$ \\
\hline Ala-AP & Ala-NA & $5.77 \pm 0.96$ & $14.13 \pm 0.50$ & $P<0.001$ \\
\hline Ser-AP & Ser-NA & $0.51 \pm 0.18$ & $0.85 \pm 0.17$ & $P<0.05$ \\
\hline Pro-AP & Pro-Na & $1.10 \pm 0.50$ & $1.08 \pm 0.43$ & NS \\
\hline Leu-AP & Leu-NA & $3.59 \pm 0.31$ & $7.70 \pm 0.20$ & $P<0.001$ \\
\hline Met-AP & Met-NA & $4.64 \pm 0.51$ & $11.80 \pm 0.60$ & $P<0.001$ \\
\hline f. Met-AP & f $\cdot$ Met-NA & $5.32 \pm 1.31$ & $4.58 \pm 0.34$ & NS \\
\hline Phe-AP & Phe-NA & $4.97 \pm 0.70$ & $12.40 \pm 0.80$ & $P<0.001$ \\
\hline Trp-AP & Trp-NA & $0.96 \pm 0.15$ & $3.18 \pm 0.05$ & $P<0.001$ \\
\hline Gly-Pro-AP & Gly-Pro-NA & $0.52 \pm 0.03$ & $0.85 \pm 0.13$ & $P<0.01$ \\
\hline Gly-Pro-Leu-AP & Gly-Pro-Leu-NA & $0.50 \pm 0.14$ & $0.80 \pm 0.14$ & $P<0.05$ \\
\hline Gly-His-Lys-AP & Gly-His-Lys-NA & $0.09 \pm 0.04$ & $0.40 \pm 0.00$ & $P<0.001$ \\
\hline Trypsinlike & TAME & $17.00 \pm 10.70$ & $8.40 \pm 3.74$ & NS \\
\hline Chymotrypsinlike & ATEE & $12.20 \pm 4.80$ & $18.60 \pm 2.40$ & $P<0.1$ \\
\hline Elastaselike & $\mathrm{Ac}(\mathrm{Ala})_{3} \mathrm{ME}$ & $8.12 \pm 8.95$ & $15.60 \pm 6.90$ & NS \\
\hline Cathepsin C & Ser-Tyr-NA & $0.41 \pm 0.09$ & $1.53 \pm 0.36$ & $P<0.01$ \\
\hline Cathepsin Df & Hemoglobin & $0.00 \pm 0.00$ & $0.01 \pm 0.00$ & $P<0.05$ \\
\hline$\alpha$-D-Glucosidase & NP-Glc & $0.20 \pm 0.10$ & $0.43 \pm 0.05$ & $P<0.01$ \\
\hline$\beta$-D-Galactosidase & NP-Gal & $0.04 \pm 0.05$ & $0.20 \pm 0.08$ & $P<0.05$ \\
\hline$\alpha$-D-Mannosidase & NP-Man & $0.08 \pm 0.09$ & $0.20 \pm 0.00$ & $P<0.05$ \\
\hline$N$-Ac- $\beta$-D-Glucosaminidase & NP-AG & $0.17 \pm 0.05$ & $0.98 \pm 0.10$ & $P<0.001$ \\
\hline Phosphatase & NPP & $1.25 \pm 0.30$ & $1.78 \pm 0.53$ & NS \\
\hline Esterase & NPA & $14.10 \pm 16.00$ & $80.10 \pm 45.40$ & $P<0.05$ \\
\hline RNase $\$($ free) & RNA & $1.08 \pm 0.17$ & $5.53 \pm 0.70$ & $P<0.001$ \\
\hline RNase (total) & RNA & $4.63 \pm 1.02$ & $9.33 \pm 1.35$ & $P<0.01$ \\
\hline
\end{tabular}

* Enzyme activities are expressed as nanomoles per minute per milligram protein.

\$ See the footnotes to Table I.

$\$$ See footnotes to Table I.

dystrophy. This was not the case. The correlation coefficient was very high, $0.80(P<0.001)$ in this case. It is unlikely that this correlation is due to only one or a few peptidases that are active against all the substrates tested. Assuming that the line passes through or near the point of origin, the slope of the regression line should represent the dystrophy-to-control ratio of the aminopeptidase activity. Thus, the slope of 2.0 would mean roughly that on the average, the activities of this series of aminopeptidases in dystrophic animals are twice those of control animals. So the steeper the slope, the greater would be the increase of these aminopeptidases in dystrophic animals.

As shown in Table $\mathrm{V}$, the slope of regression lines was generally $>1.0$ for most organs tested. The correlation coefficients were very high, ranging from 0.80 to $0.99(P<0.001)$. The intercepts on the ordinate ( $Y$-axis) were relatively small for all cases. Table $\mathrm{V}$ also includes the results of the Student's paired $t$ test. As can be seen, aminopeptidases significantly increased in most organs of dystrophic mice. Spleen, stomach, lung, and uterus did not show significant changes. It was only in the thymus that a highly significant decrease of aminopeptidases was seen. In muscle, bone, heart, submaxillary gland, pancreas, liver, brain, and testis, the increases of the enzymes were significant.

In Fig. 4, these regression lines are displayed together. It is clear that the lines representing most organs, except thymus, lung, and stomach, run above the unity lines with a $45^{\circ}$ slope. Hence, it seems reasonable that the production of aminopeptidases is increased in the whole body of dystrophic mice.

\section{DISCUSSION}

There are already quite a few reports indicating the role of increased intramuscular endopeptidases in 
TABLE IV

Comparisons of 27 Enzyme Activities in Bone in Control and Dystrophy When Expressed as Specific Activity per Milligram of Protein

\begin{tabular}{llccc}
\hline & & \multicolumn{2}{c}{ Activities* \pm SD } & Significance of \\
\cline { 3 - 4 } \multicolumn{1}{c}{ Enzyme } & \multicolumn{1}{c}{ Substrate } & Control $(n=4)$ & Dystrophy $(n=4)$ & difference \\
\hline AP-A & Glut-NA & $1.35 \pm 0.09$ & $1.73 \pm 0.25$ & $P<0.05$ \\
AP-B & Arg-NA & $5.74 \pm 0.87$ & $6.63 \pm 1.60$ & NS \\
Gly-AP & Gly-NA & $0.76 \pm 0.12$ & $1.18 \pm 0.30$ & $P<0.05$ \\
Ala-AP & Ala-NA & $8.67 \pm 1.74$ & $11.03 \pm 1.90$ & NS \\
Ser-AP & Ser-NA & $0.29 \pm 0.05$ & $0.43 \pm 0.13$ & $P<0.1$ \\
Pro-AP & Pro-Na & $0.75 \pm 0.12$ & $0.68 \pm 0.31$ & NS \\
Leu-AP & Leu-NA & $5.07 \pm 0.72$ & $6.45 \pm 0.72$ & $P<0.05$ \\
Met-AP & Met-NA & $7.08 \pm 1.11$ & $10.98 \pm 1.51$ & $P<0.05$ \\
f-Met-AP & f-Met-NA & $6.71 \pm 1.14$ & $5.25 \pm 0.66$ & $P<0.1$ \\
Phe-AP & Phe-NA & $6.54 \pm 0.94$ & $9.00 \pm 1.53$ & $P<0.05$ \\
Trp-AP & Trp-NA & $1.54 \pm 0.25$ & $2.13 \pm 0.42$ & $P<0.1$ \\
Gly-Pro-AP & Gly-Pro-NA & $0.93 \pm 0.06$ & $0.85 \pm 0.19$ & NS \\
Gly-Pro-Leu-AP & Gly-Pro-Leu-NA & $0.48 \pm 0.08$ & $0.53 \pm 0.10$ & NS \\
Gly-His-Lys-AP & Gly-His-Lys-NA & $0.10 \pm 0.10$ & $0.18 \pm 0.05$ & NS \\
Trypsinlike & TAME & $22.02 \pm 4.90$ & $24.20 \pm 7.70$ & NS \\
Chymotrypsinlike & ATEE & $11.80 \pm 5.20$ & $22.50 \pm 8.60$ & $P<0.1$ \\
Elastaselike & Ac(Ala) ME & $19.50 \pm 5.50$ & $16.00 \pm 4.90$ & NS \\
Cathepsin C & Ser-Tyr-NA & $0.72 \pm 0.10$ & $0.73 \pm 0.12$ & NS \\
Cathepsin D & Hemoglobin & $0.01 \pm 0.00$ & $0.01 \pm 0.00$ & NS \\
$\alpha$-D-Glucosidase & NP-Glc & $0.31 \pm 0.08$ & $0.58 \pm 0.29$ & NS \\
$\beta$-D-Galactosidase & NP-Gal & $0.50 \pm 0.22$ & $0.43 \pm 0.05$ & NS \\
$\alpha$-D-Mannosidase & NP-Man & $0.13 \pm 0.12$ & $0.25 \pm 0.13$ & NS \\
$N$-Ac- $\beta$-D-Glucosaminidase & NP-AG & $1.56 \pm 0.56$ & $2.60 \pm 0.56$ & $P<0.05$ \\
Phosphatase & NPP & $8.82 \pm 3.57$ & $3.30 \pm 0.73$ & NS \\
Esterase & NPA & $18.00 \pm 20.60$ & $44.70 \pm 20.20$ & NS \\
RNase $\$$ (free) & RNA & $8.70 \pm 2.14$ & $14.50 \pm 2.60$ & $P<0.05$ \\
RNase (total) & RNA & $11.40 \pm 2.60$ & $15.60 \pm 2.90$ & $P<0.1$ \\
\hline
\end{tabular}

* Enzyme activities are expressed as nanomole per minute per milligram of protein.

\$ See the footnotes to Table I.

$\$$ See footnotes to Table I.

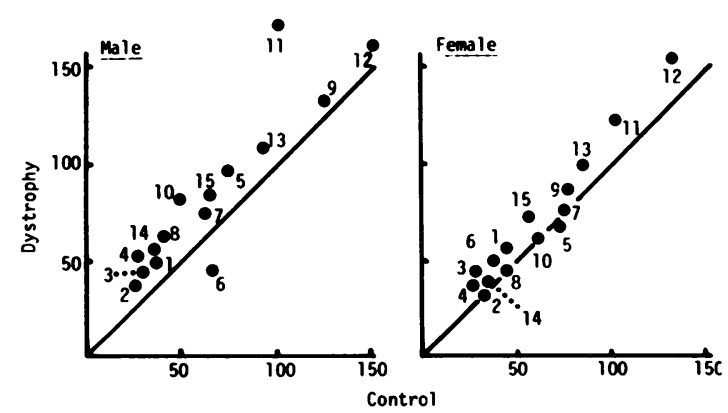

Figure 2 Comparisons, between control and dystrophy, of protein contents in various organs. The organ names corresponding to the numbers shown in the figure are the same as cited in Fig. 3. Most of the circles are located above the unity line, suggesting that the protein metabolism is abnormal in dystrophic mice. The difference between dystrophic and control animals was statistically significant according to Student's paired $t$ test $(P<0.05$ for male and $P<0.005$ for female). muscular dystrophy (5-11). Sanada et al. (13) reported that one of these enzymes, a serine protease, is of mastcell origin. However, they still believe that this enzyme plays an important role in degradation of myofibrillar structural proteins (24). Although our results are consistent with these observations, our studies revealed many other abnormalities as well. As far as muscles and bones are concerned, almost all enzyme activities tested were significantly elevated in dystrophic mice. The reason we separated fore limbs and hind limbs was that hind limbs are known to be affected first by the disease. However, we did not find any particular difference between these, as far as the enzyme contents are concerned. Although it would have been more useful to compare red and white muscles, it was not possible for us to separate these in dystrophic mice, because of the atrophy of muscle. This trial is being done in our study on chicken muscle dystrophy. 


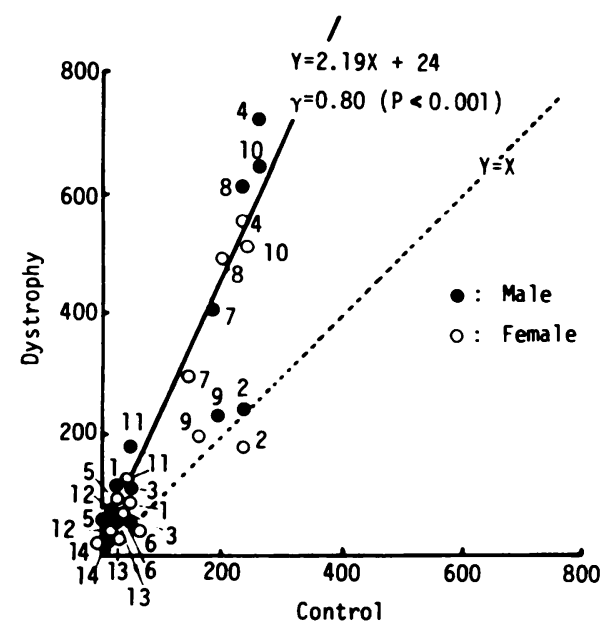

Figure 3 Comparison of 14 kinds of aminopeptidase activities in muscle in control and dystrophic mice. The values for dystrophy (expressed as nanomoles per minute per gram wet weight of organ) are plotted against those for control. The unity line is indicated with $45^{\circ}$ slope. The numbers shown in the figure represent each enzyme as follows: (1) AP-A, (2) AP-B, (3) Gly-AP, (4) Ala-AP, (5) Ser-AP, (6) Pro-AP, (7) Leu-AP, (8) Met-AP, (9) f·Met-AP, (10) Phe-AP, (11) Trp-AP, (12) Gly-Pro-AP, (13) Gly-Pro-Leu-AP, (14) Gly-His-Lys-AP. Most of the closed and open circles are along a regression line, meaning that the changes of these aminopeptidases are somehow correlated with each other.

Many aminopeptidase activities were found to be remarkably increased in dystrophic mice. So far, most of the aminopeptidases have not been fully isolated and their properties are little understood. Our method of assessing the activity of these enzymes using $\beta$-NA may be limited in its specificity, because it is possible that an AP could hydrolyze several kinds of $\beta$-NA. However, according to our previous studies, AP-B, AP-A and f.Met-AP purified by the affinity chromatography using aminopeptidase inhibitors, bestatin and amastatin, show relatively high substrate specificity against their corresponding $\beta$-naphthylamide, Arg-NA, Asp-NA and f.Met-AP (25). ${ }^{2}$ As we have reported $(21,26,27)$, the activities of several aminopeptidases have been found in the membrane fraction of all kinds of cells tested, and AP-A was suggested to be one of the transformation-sensitive proteins. Considering these observations, the observed increase of aminopeptidases in many organs of dystrophic mice should be very important.

In addition to aminopeptidases, many other enzyme activities were increased in dystrophic mice. Moreover, these abnormalities were not limited to muscle but widely distributed in the whole body. At the present time, we have no precise data concerning the subcellular source of the enzymes we tested. A large part of these enzymes probably come from lysosomes. However, we previously demonstrated aminopeptidases, phosphatase, and esterase on cellular membranes of various organs $(21,27)$. It is evident that more studies need to be done using subcellular fractions of these organs. It is also noteworthy that protein

${ }^{2}$ Suda, H., K. Yamamoto, T. Aoyagi, and H. Umezawa. Purification and properties of $\mathrm{N}$-formylmethionine aminopeptidase from rat liver. Biochim. Biophys. Acta. Manuscript submitted for publication.

TABLE V

Difference between Aminopeptidase Activities in Various Organs of Control and Dystrophic Mice

\begin{tabular}{|c|c|c|c|c|c|c|}
\hline \multirow[b]{2}{*}{ Organ } & \multicolumn{3}{|c|}{ Least-square method } & \multicolumn{3}{|c|}{ Paired $t$ test } \\
\hline & Regression lines & Correlation & Significance & $t$ values & Significance & $n$ \\
\hline 1. Muscle (forelimb) & $Y=2.19 X+24$ & $\gamma=0.80$ & $P<0.001$ & 4.42 & $P<0.001$ & 28 \\
\hline 2. Muscle (hindlimb) & $Y=1.95 X+26$ & $\gamma=0.85$ & $P<0.001$ & 4.14 & $P<0.001$ & 28 \\
\hline 3. Bone (forelimb) & $Y=1.73 X+4$ & $y=0.94$ & $P<0.001$ & 4.51 & $P<0.001$ & 28 \\
\hline 4. Bone (hindlimb) & $Y=1.77 X+10$ & $\gamma=0.93$ & $P<0.001$ & 4.58 & $\dot{P}<0.001$ & 28 \\
\hline 5. Heart & $Y=1.21 X+4$ & $\gamma=0.97$ & $P<0.001$ & 3.86 & $P<0.001$ & 28 \\
\hline 6. Uterus & $Y=1.01 X+22$ & $\gamma=0.91$ & $P<0.001$ & 0.64 & NS & 14 \\
\hline 7. Spleen & $Y=1.04 X-20$ & $\gamma=0.96$ & $P<0.001$ & -0.18 & NS & 28 \\
\hline 8. Thymus & $Y=0.73 X+7$ & $\gamma=0.93$ & $P<0.001$ & -4.10 & $P<0.001$ & 28 \\
\hline 9. Submaxillary gland & $Y=1.15 X+5$ & $\gamma=0.99$ & $P<0.001$ & 3.98 & $P<0.001$ & 28 \\
\hline 10. Stomach & $Y=0.93 X+40$ & $\gamma=0.90$ & $P<0.001$ & 1.21 & NS & 28 \\
\hline 11. Pancreas & $Y=2.06 X-132$ & $\gamma=0.92$ & $P<0.001$ & 3.28 & $P<0.005$ & 28 \\
\hline 12. Liver & $Y=1.10 X+13$ & $\gamma=0.94$ & $P<0.001$ & 2.20 & $P<0.05$ & 28 \\
\hline 13. Kidney & $Y=1.01 X+81$ & $\gamma=0.98$ & $P<0.001$ & 1.47 & NS & 28 \\
\hline 14. Brain & $Y=1.09 X+16$ & $\gamma=0.96$ & $P<0.001$ & 3.01 & $P<0.01$ & 28 \\
\hline 15. Lung & $Y=0.84 X+47$ & $\gamma=0.92$ & $P<0.001$ & -0.03 & NS & 28 \\
\hline 16. Testis & $Y=2.86 X+62$ & $\gamma=0.88$ & $P<0.001$ & 3.31 & $P<0.005$ & 14 \\
\hline
\end{tabular}




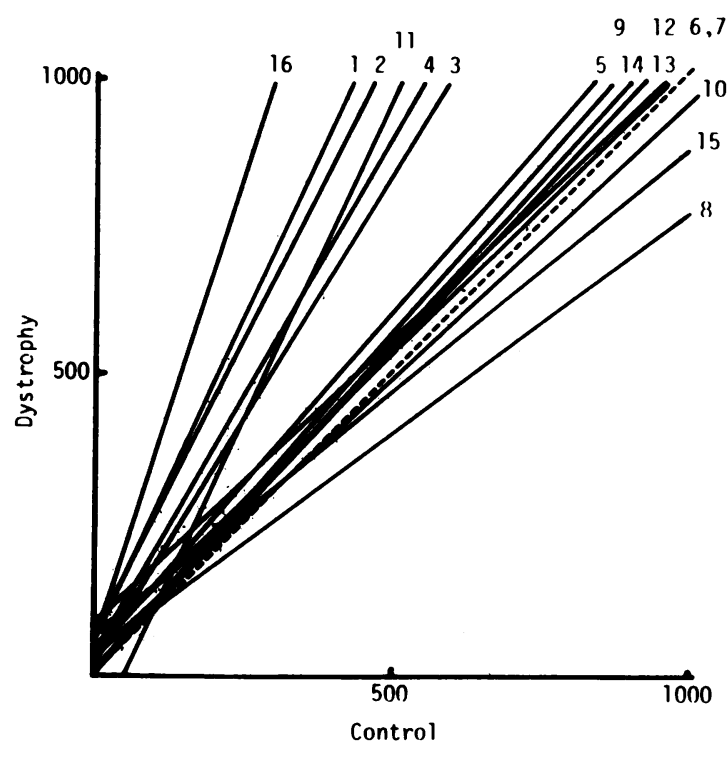

FIGURE 4 Regression lines for comparisons of aminopeptidases in various organs between control and dystrophy. These lines were obtained statistically by the least-square method. The ordinate is for the values (expressed as nanomole per minute per gram wet weight of organ) of dystrophic mice and the abscissa for those of control. The numbers represent each organ as follows: (1) muscle (fore limb), (2) muscle (hind limb), (3) bone (fore limb), (4) bone (hind limb), (5) heart, (6) uterus, (7) spleen, (8) thymus, (9) submaxillary gland, (10) stomach, (11) pancreas, (12) liver, (13) kidney, (14) brain, (15) lung, (16) testis. Regression lines for most organs except thymus, lung, and stomach lie above the unity line, indicating that aminopeptidases are generally increased in these organs of dystrophic mice.

content per unit wet weight of organs was significantly increased in many organs examined in dystrophic mice. This observation may seem odd, since many of previous studies reported an extensive loss of contractile protein in diseased muscle. However, there are several studies reporting an increased rate of protein synthesis in dystrophic muscle that is seemingly inconsistent with muscle wasting (28). Because the loss of protein could arise from either an increased rate of degradation or a decreased rate of protein synthesis, protein content should be dependent on the increase of protein catabolism and increase of protein synthesis, causing a faster turnover. Protein content in muscles of dystrophic animals may be different, depending on the stage of disease and the animal models.

The present study suggests extensive abnormalities in enzyme activities associated with metabolism of carbohydrate, protein, and RNA in this pathologic condition. Several endopeptidase inhibitors found in our laboratory have been used to suppress the muscle degeneration in muscular dystrophy, and some reports endorsed the usefulness of leupeptin, antipain, and/or pepstatin for this purpose $(5,6)$. However, it does not seem that we should limit our scope to the already available information. Muscle dystrophy should be studied from various enzymic aspects, since this may be helpful in finding some new therapeutic approaches. Besides inhibitors of endopeptidases, AP inhibitors such as amastatin and bestatin should also be tried to test their effects on dystrophy.

\section{ACKNOWLEDGMENTS}

This study was supported by grant 4, 1978, from National Center for Nervous, Mental, and Muscular Disorders (NCNMMD) of the Ministry of Health and Welfare, Japan.

\section{REFERENCES}

1. Umezawa, H. 1972. Enzyme Inhibitors of Microbial Origin. University of Tokyo Press, Tokyo. 1-52.

2. Aoyagi, T., and H. Umezawa. 1975. Structures and activities of protease inhibitors of microbial origin. In Proteases and Biological Control. E. Reich, D. B. Rifkin, and E. Shaw, editors. Cold Spring Harbor Laboratory, New York. 429-454.

3. Umezawa, H., and T. Aoyagi. 1977. Activities of protease inhibitors of microbial origin. In Protease in Mammalian Cells and Tissues. A. J. Barrett, editor. North-Holland Publishing Co., Amsterdam. 637-662.

4. Aoyagi, T., and H. Umezawa. 1979. Hydrolytic enzymes on the cellular surface and their inhibitors found in microorganisms. In Industrial and Clinical Enzymology. L. J. Vitale and V. Simeon, editors. FEBS (Fed. Eur. Biochem. Soc.) Lett. 61: 89-99.

5. Stracher, A., E. B. McGowan, and S. A. Shafiq. 1978. Muscular dystrophy: inhibition of degeneration in vivo with protease inhibitors. Science (Wash., D. C.). 200: 50-51.

6. Stracher, A., E. B. McGowan, and S. A. Shafiq. 1979. In vivo effect of protease inhibitors in denervation atrophy. Exp. Neurol. 66: 611-618.

7. Iodice, A. A. 1976. The inhibition by pepstatin of cathepsin D and autolysis of dystrophic muscle. Life Sci. 19: 1351-1358.

8. Kar, N. C., and C. M. Pearson. 1977. Hydrolytic enzymes and human muscular dystrophy. In Pathogenesis of Human Muscular Dystrophies. L. P. Rowland, editor. Excerpta Medica, Amsterdam, The Netherlands. 387-394.

9. Toyooka, T., T. Shimizu, and T. Masaki. 1978. Inhibition of proteolytic activity of calcium activated neutral protease by leupeptin and antipain. Biochem. Biophys. Res. Commun. 82: 484-490.

10. Ishiura, S., H. Murofiushi, K. Suzuki, and K. Imahori. 1978. Studies of a calcium-activated neutral protease from chicken skeletal muscle. J. Biochem. (Tokyo). 84: 225-230.

11. Goll, D. E., A. Okitani, W. R. Dayton, and W. J. Reville. 1978. A Ca-activated muscle protease in myofibrillar protein turnover. In Protein Turnover and Lysosome Function. H. L. Segal and D. J. Doyle, editors. Academic Press Inc., New York. 587-588.

12. Bird, J. W. C., A. M. Spanier, and W. N. Schwartz. 1978. Cathepsins $B$ and D: proteolytic activity and ultrastructural localization in skeletal muscle. In Protein Turnover and Lysosome Function. H. L. Segal and D. J. 
Doyle, editors. Academic Press Inc., New York. 589604.

13. Sanada, Y., N. Yasogawa, and N. Katsunuma. 1978. Serine protease in mice with hereditary muscular dystrophy. J. Biochem. (Tokyo). 83: 27-33.

14. McGowan, E. B., S. A. Shafiq, and A. Stracher. 1976. Delayed degeneration of dystrophic and normal muscle cell cultures treated with pepstatin, leupeptin and antipain. Exp. Neurol. 50: 649-657.

15. Libby, P., and A. L. Goldberg. 1978. Leupeptin, a protease inhibitor, decreases protein degradation in normal and diseased muscles. Science (Wash., D. C.). 199: 534-536.

16. Chelmicka-Schorr, E. E., B. G. W. Amason, K. E. Astrom, and Z. Darzynkiewicz. 1978. Treatment of mouse muscular dystrophy with the protease inhibitor pepstatin. J. Neuropathol. Exp. Neurol. 37: 263-268.

17. Umezawa, H., T. Aoyagi, H. Suda, M. Hamada, and T. Takeuchi. 1976. Bestatin, an inhibitor of aminopeptidase B, produced by actinomycetes. J. Antibiot. (Tokyo). 29: 97-99.

18. Aoyagi, T., S. Miyata, M. Nanbo, F. Kojima, M. Matsuzaki, M. Ishizuka, T. Takeuchi, and H. Umezawa. 1969. Biological activities of leupeptins. J. Antibiot. (Tokyo). 22: 558-568.

19. Aoyagi, T., S. Kunimoto, H. Morishima, T. Takeuchi, and H. Umezawa. 1971. Effect of pepstatin on acid proteases. J. Antibiot. (Tokyo). 24: 687-694.

20. Aoyagi, T., K. Nerome, J. Suzuki, T. Takeuchi, and H. Umezawa. 1974. Change of enzyme activities during the early stage of influenza virus infections. Biochem. Biophys. Res. Commun. 60: 1178-1184.

21. Aoyagi, T., M. Nagai, M. Iwabuchi, W. S. Liaw, T. Andoh, and H. Umezawa. 1978. Aminopeptidase activities on the surface of mammalian cells and their alterations associated with transformation. Cancer Res. 38: 3505-3508.

22. Meyer, D. H., W. L. Meyer, and B. A. Kakulas. 1975. Studies on the physiological perturbation of the neutral ribonuclease II-inhibitor system. In Recent Advances in Myology. W. G. Bradley, D. Gardner-Medwin, and J. N. Walton, editors. Excerpta Medica, Amsterdam. 277-282.

23. Lowry, O. H., N. J. Rosebrough, A. L. Farr, and R. J. Randall. 1951. Protein measurement with the Folin phenol reagent. J. Biol. Chem. 193: 265-275.

24. Katsunuma, N., T. Noda, and Y. Sanada. 1979. Studies of intracellular proteases for myofibrillar structural proteins. In Current Research in Muscular Dystrophy, Japan. S. Ebashi, editor. Tokyo. 53-54.

25. Tobe, H., F. Kojima, T. Aoyagi, and H. Umezawa. 1980. Purification by affinity chromatography using amastain and properties of amino-peptidase $A$ from pig kidney. Biochim. Biophys. Acta. 613: 459-468.

26. Aoyagi, T., H. Suda, M. Nagai, H. Tobe, J. Suzuki, T. Takeuchi, and H. Umezawa. 1978. Release of a plasma membrane-bound triaminopeptidase activity from mammalian cells by thermolysin. Biochem. Biophys. Res. Commun. 80: 435-442.

27. Aoyagi, T., H. Suda, M. Nagai, K. Ogawa, J. Suzuki, T. Takeuchi, and H. Umezawa. 1976. Aminopeptidase activities on the surface of mammalian cells. Biochim. Biophys. Acta. 452: 131-143.

28. Goldberg, A. L., G. E. Griffin, and J. F. Dice. 1977. Regulation of protein turnover in normal and dystrophic muscle. In Pathogenesis of Human Muscular Dystrophies. L. P. Rowland, editor. Excerpta Medica, Amsterdam, The Netherlands. 376-385. 